\title{
Hvor smart er du?
}

Diskusjoner om personers mentale evner er ikke noe nytt i psykiatrien og rettssalene. I denne artikkelen fra nr. 16/1923 (Tidsskr Nor Lægeforen 1923; 43: 882-92) ser vi at det også da var ulike meninger om hvordan man skulle kategorisere ut ifra intelligens. Ikke bare er selve inndelingen interessant, men også begrepene som ble brukt.

\section{Om intelligensprøver for voksne.}

(Foredrag ved den skandinaviske psykiatriske kongres i Stockholm den 5te september 1922)

Av Hans Evensen, Gaustad asyl.

I retspsykiatriske tilfælder, overalt hvor intelligensmangelen gjør utslaget, forlanger den retsmedicinske kommission, at der ikke bare henvises til et subjektivt skjøn, som ikke lar sig kontrollere, men at der skal være foretat en ordentlig intelligensundersøkelse, som i tilfælde kan efterprøves. (...)

Skal man kunne skille ut undermaalerne og de særs begavede, trænger man en gradering av intelligensen, og det vil da være det formaalstjenligste at lægge IQ til grund. Terman har oppstillet følgende skala:

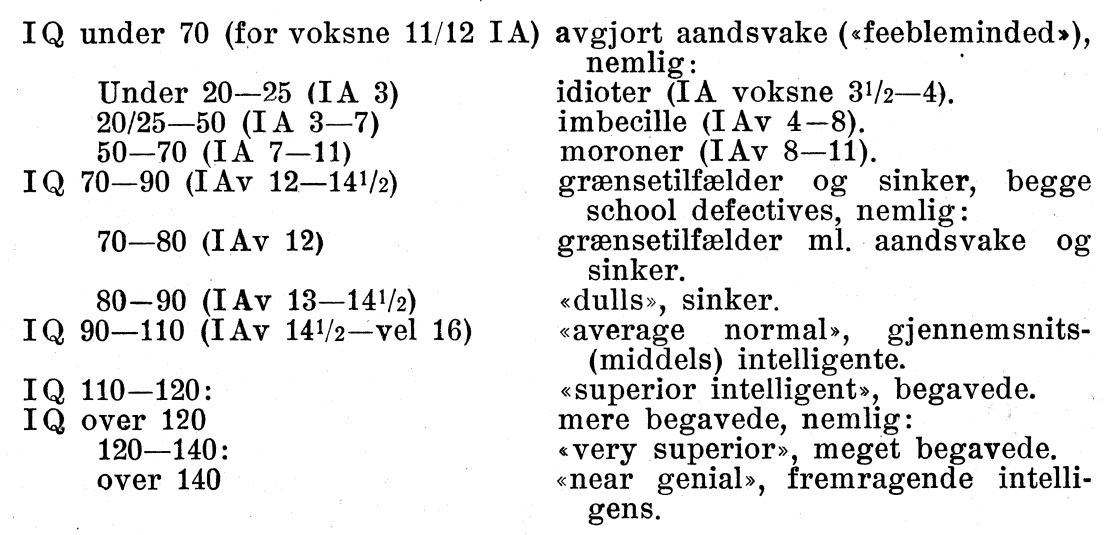

Hvad hyppigheten av hver klasse angaar, har Terman for skolebarn fundet, at 60 pct. av eleverne var middelsbegavede (stod mellem 90-110), mens 15 pct. var indskrænkede («dulls» IQ 80-90) og like mange begavede (IQ 110-120). De høiere grader av intelligens var saa sjeldne (IQ 1401 av 300, over 140 bare 1 av 10 000), at de ikke er noget at regne med.

Der raader et fuldstændig virvar med hensyn til betegnelserne for de forskjellige intelligensgrader, og grænserne mellem idioti, imbecillitet og debilitet optrækkes høist forskjellig. Healy sætter saaledes grænsen for idioti allerede ved 2 aarstrinnet, for imbecillitet mellem 2 og 7 aar, for «moroner» mellem 7 og 12 aar. Andre bruker uttrykket idioti om alle tilbakesatte til og med 12 aarstrinnet og taler om høierestående idioter. 